\title{
Insulin Matters: A Practical Approach to Basal Insulin Management in Type 2 Diabetes
}

\author{
Lori Berard · Noreen Antonishyn - Kathryn Arcudi - Sarah Blunden • \\ Alice Cheng · Ronald Goldenberg • Stewart Harris · Shelley Jones • \\ Upender Mehan · James Morrell · Robert Roscoe · Rick Siemens • \\ Michael Vallis · Jean-François Yale
}

Received: January 12, 2018 / Published online: February 23, 2018

(C) The Author(s) 2018. This article is an open access publication

\section{ABSTRACT}

It is currently estimated that 11 million Canadians are living with diabetes or prediabetes. Although hyperglycemia is associated with serious complications, it is well established that improved glycemic control reduces the risk of microvascular complications and can also reduce cardiovascular $(\mathrm{CV})$ complications over the long term. The UKPDS and ADVANCE

Enhanced content To view enhanced content for this article go to https://doi.org/10.6084/m9.figshare. 5822136 .

\section{Berard ( $\square)$}

Winnipeg Regional Health Authority, Winnipeg Diabetes Research Group, Health Sciences Centre, Winnipeg, MB, Canada

e-mail: ldberard@gmail.com

N. Antonishyn

Department of Endocrinology, Alberta Health

Services, Edmonton, AB, Canada

\section{K. Arcudi}

Diabetes Clinic, The Montreal West Island Integrated University Health and Social Services Centre (Lakeshore General Hospital), Pointe-Claire, QC, Canada

\section{S. Blunden}

Diabetes Education, LMC Diabetes and

Endocrinology, Montreal, QC, Canada

\section{A. Cheng}

Division of Endocrinology and Metabolism, St.

Michael's Hospital, Toronto, ON, Canada landmark trials have resulted in diabetes guidelines recommending an A1C target of $\leq 7.0 \%$ for most patients or a target of $\leq 6.5 \%$ to further reduce the risk of nephropathy and retinopathy in those with type 2 diabetes (T2D), if it can be achieved safely. However, half of the people with T2D in Canada are not achieving these glycemic targets, despite advances in diabetes pharmacological management. There are many contributing factors to account for this poor outcome; however, one of the major factors is the delay in treatment advancement, particularly a resistance to insulin initiation and intensification. To simplify the process of

\section{A. Cheng}

Trillium Health Partners, Credit Valley Hospital, Mississauga, ON, Canada

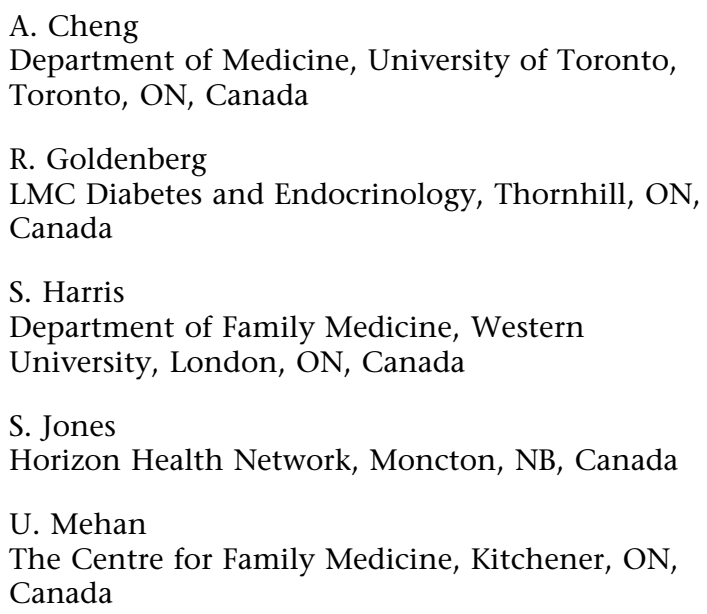


initiating and titrating insulin in T2D patients, a group of Canadian experts reviewed the evidence and best clinical practices with the goal of providing guidance and practical recommendations to the diabetes healthcare community at large. This expert panel included general practitioners (GPs), nurses, nurse practitioners, endocrinologists, dieticians, pharmacists, and a psychologist. This article summarizes the panel recommendations.

Keywords: Basal insulin; Glycemic target; Insulin initiation; Insulin titration; Patient barriers; Patient follow-up; Treatment delay; Type 2 diabetes

\section{BASAL INSULIN INITIATION}

\section{Do We Still Need Insulin?}

Type 2 diabetes (T2D) is a progressive disorder characterized by multiple pathophysiological defects. The core defects include insulin resistance in the muscle and liver and impaired insulin secretion due to $\beta$-cell failure $[1,2]$. The progressive nature of the disease is such that it requires therapy to be intensified over time to compensate for the ongoing $\beta$-cell deficiency [2-4]. At the time of T2D diagnosis, more than $50 \%$ of $\beta$-cells have already been lost, and continue to decline at an average rate of $5 \%$ per year $[1,2,5]$. Therefore, the use of insulin is an appropriate option at any point in the management of $\mathrm{T} 2 \mathrm{D}$ to replace the insulin that the pancreas is unable to produce sufficiently $[1,6]$.

U. Mehan

Department of Family Medicine, McMaster

University, Hamilton, ON, Canada

J. Morrell

Diabetes Services, Island Health, Victoria, BC, Canada

R. Roscoe

Diabetes Education Centre, Saint John Regional

Hospital, Saint John, NB, Canada

R. Siemens

London Drugs Pharmacy, Lethbridge, AB, Canada
In fact, when the maximum output of insulin has decreased to $15 \%$ or $20 \%$ of normal, noninsulin anti-hyperglycemic agents can no longer sustain glycemic control and insulin supplementation becomes a necessity [5]. The usual starting point for insulin therapy in T2D is with basal insulin owing to its simplicity and lower risk of hypoglycemia [7].

\section{When and in Whom to Initiate Insulin in $\mathrm{T} 2 \mathrm{D}$}

The panel recommendations as to when and in whom to initiate insulin are summarized in Table 1.

\section{What are the Barriers to Insulin Initiation?}

Clinical inertia, defined as the failure on the part of the provider to advance therapy when required, adversely affects timely management of T2D [9-12]. Insulin is often initiated late in the course of the disease, after failure with multiple antihyperglycemic agents, and at glycemic values well above the recommended targets [11-15]. In Canada, mean A1C levels are $>8.5 \%$ and mean diabetes duration is $\geq 9$ years before initiation of basal insulin in T2D patients $[13,15]$. A UK retrospective study of pharmacologically treated T2D patients on one, two, or three oral antihyperglycemic agents reported that the median time to insulin initiation was $>7$ years with an $\mathrm{A} 1 \mathrm{C} \geq 7.0 \%$ and the mean A1C levels at initiation was $>9.0 \%$ [12].

There are many barriers that contribute to this delay in initiation and intensification of

\author{
M. Vallis \\ Behaviour Change Institute, Nova Scotia Health \\ Authority, Halifax, NS, Canada \\ M. Vallis \\ Department of Family Medicine, Dalhousie \\ University, Halifax, NS, Canada \\ J.-F. Yale \\ Department of Medicine, McGill University, \\ Montreal, QC, Canada
}


Table 1 When and in whom to initiate insulin in T2D

\begin{tabular}{|c|c|}
\hline $\begin{array}{l}\text { When to consider insulin } \\
\text { initiation }\end{array}$ & $\begin{array}{l}\text { When NOT to initiate } \\
\text { insulin }\end{array}$ \\
\hline $\begin{array}{l}\text { Maximally tolerated non- } \\
\text { insulin agents but A1C } \\
\text { above the individualized } \\
\text { target (usually } 7.0 \% \text { ) }\end{array}$ & $\begin{array}{l}\text { There are no } \\
\text { contraindications for the } \\
\text { use of insulin but insulin } \\
\text { may not be appropriate }\end{array}$ \\
\hline New diagnosis $\mathrm{A} 1 \mathrm{C} \geq 8.5 \%$ & for: \\
\hline $\begin{array}{l}\text { Metabolic decompensation } \\
\text { End-organ failure }\end{array}$ & $\begin{array}{l}\text { Some older, asymptomatic } \\
\text { patients, who may not } \\
\text { gain sufficient benefit }\end{array}$ \\
\hline $\begin{array}{l}\text { Patients with previous or } \\
\text { current gestational }\end{array}$ & $\begin{array}{l}\text { because of short life } \\
\text { expectancy }\end{array}$ \\
\hline dial & People limited in their \\
\hline Acute illness & capacity (physical or \\
\hline Prolonged course of steroids & cognitive) to manage their \\
\hline $\begin{array}{l}\text { Intolerance to oral } \\
\text { medications }\end{array}$ & $\begin{array}{l}\text { diabetes who are at greater } \\
\text { risk of hypoglycemia }\end{array}$ \\
\hline
\end{tabular}

Any time you consider this is an appropriate option for your patients from diagnosis onwards

[8]; http://guidelines.diabetes.ca/fullguidelines; http:// www.rcn.org.uk; https://www.rcn.org.uk/professionaldevelopment/publications/pub-002254

insulin in T2D. It is important to emphasize that many of these barriers reflect the attitudes and beliefs of both patient and provider. Identifying and addressing both provider and patient beliefs and attitudes are therefore essential to mitigate those barriers (Tables 2 and $3)$.

\section{What is Your Role in Insulin Therapy?}

Success in overcoming patient barriers relies greatly on listening to the patient and proactively addressing their fears and concerns $[55,56]$. Open dialogue with the patient throughout the continuum of diabetes management, with an emphasis on the positive benefits of insulin therapy, will significantly enhance the outcomes for patients with diabetes. See Table 4 for review of action points with your patient.

\section{BASAL INSULIN DOSE AND TITRATION RECOMMENDATIONS}

In light of the persistent barriers contributing to delays in diabetes management with insulin, there is an urgent need for a simplified and practical approach to the initiation and intensification of insulin. Complex regimens and unrealistic targets can worsen the patient's engagement in the process and ultimately the patient's well-being [3, 4, 57]. Simplification allows for empowerment by engaging the patient in doable tasks, which provides the context for behavior shaping (next step goals) and self-efficacy (confidence in the face of barriers) [58].

\section{What Do We Want in a Basal Insulin Recommendation?}

- A starting dose that can be safely applied and individualized.

- A titration schedule that is simple and can be safely patient-driven, with a fasting blood glucose (FBG) target that can be individualized. Patient-driven titration schedules are as effective as provider-driven titration schedules [19, 59-64] and engage the patient, which in turn can lower barriers to insulin therapy $[4,65,66]$.

- Clear instructions to the patient on how the dose will be titrated, to manage expectations which will empower the patient and improve adherence to therapy [3, 4, 16, 66].

- Recognition that insulin initiation and titration are two separate behaviors for the patient, each of which needs to be addressed in relation to patient readiness to change.

\section{How to Select a Basal Insulin?}

Three generations of basal insulins are available in Canada. The first generation of basal insulin is NPH, a human insulin that has been available 
Table 2 Provider barriers

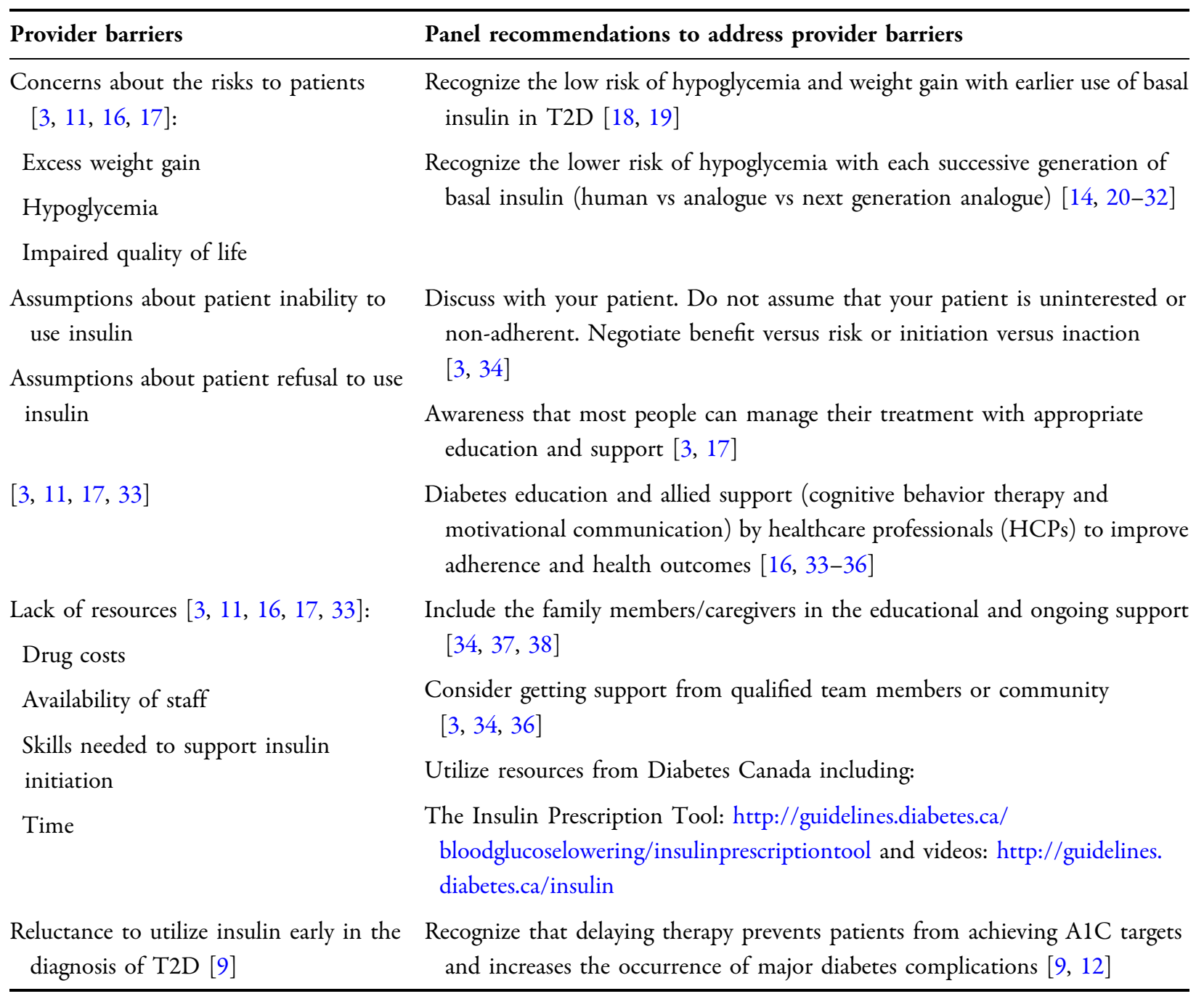

for many decades, since 1946 . The basal analogues (insulins detemir and glargine (Gla-100)) emerged in the 2000s and provided longer duration of action, improved day-to-day variability, reduced hypoglycemia, especially nocturnal, and did not require resuspension (as does NPH) [67]. A next generation of long-acting basal insulins-insulins glargine $300 \mathrm{U} / \mathrm{mL}$ (Gla-300) and degludec-have emerged with an extended action profile, improved safety, and the advantage of being administered in smaller volumes [29]. Table 5 summarizes the main characteristics of the currently available basal insulins. The panel recognizes that the choice of basal insulin may depend on access, cost, and clinical judgment with respect to the patient's individual needs and lifestyle [29].

\section{How to Dose?}

There are several important concepts to remember when dosing basal insulin: (a) the starting dose will be wrong; (b) there is no maximal insulin dose; (c) titration of insulin dose is the key [8]. Each of these concepts needs to be explicitly discussed and understood by the patient in order for titration to be successful. Despite $92 \%$ of physicians agreeing that 
Table 3 Patient barriers [39-43]

\section{Concern Panel recommendations}

Fear of needles or apprehension

Demonstrate injection technique: show the insulin pen and small needle tips. Apply the toward injections principles of systematic desensitization (self-controlled exposure)

Feeling that insulin is too Highlight that the injection is into subcutaneous tissue, not a vein complicated

$[3,11,16,33,44]$

Invite patient to try these without insulin, in your office (i.e., dry injection); give first injection together with patient to observe, support and ensure correct administration of insulin

Educating on injections: see

http://www.fit4diabetes.com/canada-english/fit-recommendations/

Feeling that this is a personal

Pro-action. Do not wait to talk about insulin once the patient needs insulin. Explain from failure $[3,11,16,33,45]$ the time of diagnosis that insulin is a likely treatment option in the course of T2D [46]

Discuss with the patient, using decisional balance analysis (pros and cons), that need to advance therapy is due to the progressive nature of diabetes, not because the patient has done something wrong

Belief that insulin causes

Insulin is a natural hormone and a replacement therapy [42]

diabetes complications

$[3,11,16,33]$

Explain why insulin becomes necessary for most patients with diabetes eventually; it is not a punishment [46]

Explain that use of insulin will help achieve glycemic target and minimize the risk of complications $[47,48]$

Concerns over hypoglycemia

$(\mathrm{BG}<4.0 \mathrm{mmol} / \mathrm{L})$

$[3,11,16,33,49-52]$

Reassure the patient that most hypoglycemic episodes are mild. Severe hypoglycemia (defined as requiring assistance by another person) is relatively rare ${ }^{a}$ [52] http:// guidelines.diabetes.ca/browse/chapter14;

[53] http://guidelines.diabetes.ca/browse/chapter13; [20, 29, 42, 47, 54]

Educate the patient on how to recognize and respond to symptoms [52] http://guidelines. diabetes.ca/browse/chapter14

Make sure the patient and partner/family (if applicable) know how to recognize, treat, and avoid hypoglycemia, and how to self-adjust insulin [34]

Choose insulins and regimens with lower rates of hypoglycemia $[14,29]$

Use systematic desensitization to allow the patient to work from a psychologically safe zone to a medically safe zone

Concerns over weight gain

$[3,11,16,33]$

Encourage healthy diet and moderate exercise. Monitor weight. http://guidelines.diabetes. ca/fullguidelines

Combine insulin with metformin or other NIAHA with weight benefit. http://guidelines. diabetes.ca/cdacpg_resources/CPG_Quick_Reference_Guide_WEB.pdf [14, 29]

Explain that weight gain with basal insulin regimens is small especially with newer basal insulin analogues $(1-2 \mathrm{~kg})[14,20,26-29,32]$ 
Table 3 continued

\begin{tabular}{lc}
\hline Concern & Panel recommendations \\
\hline $\begin{array}{l}\text { Belief that insulin can never be } \\
\text { stopped and will restrict }\end{array}$ & $\begin{array}{c}\text { Offer a 3-month trial period with subsequent reassessment. http://guidelines.diabetes.ca/ } \\
\text { fullguidelines }\end{array}$ \\
Recall that engaging the patient in the decision empowers them and leads to better \\
outcomes [3, 4 , 16, 33, 42] \\
Prescribe once-daily basal insulin that minimizes inconvenience and is easy to use. http:// \\
guidelines.diabetes.ca/bloodglucoselowering/insulinprescriptiontool
\end{tabular}

NIAHA non-insulin anti-hyperglycemic agent, $B G$ blood glucose

${ }^{a}$ In UKPDS, the annual incidence of severe hypoglycemia in insulin-treated patients was $<3 \%$. With the newer longacting basal insulins this is even lower (2.3\%) [47]

Table 4 A new LEASE on insulin management [55]

$\begin{aligned} & \text { Listen and } \\ & \text { ask }\end{aligned}$
Invite discussion, show conviction of belief and supportive body language
Educate $\quad$ Ask permission to educate about the importance of insulin, the progressive nature of the disease, how to self-
manage their disease
Address $\quad \begin{aligned} & \text { Proactively address patient concerns that may deter initiation and adherence to insulin } \\ & \text { Ask questions, identify the barriers, outline goals }\end{aligned}$
Support $\quad \begin{aligned} & \text { Enlist support of diabetes management team } \\ & \text { Empower } \\ & \text { Encourage and educate the patient on self-management: demonstrate how the pen works and let them try it, } \\ & \text { explain how to take medications, how to self-monitor blood glucose, how to prevent and treat } \\ & \text { hypoglycemia, reinforce healthy lifestyle and diet }\end{aligned}$
$\begin{aligned} & \text { Be comfortable with the principle of shaping: in other words, with repetition and support for next step goals, } \\ & \text { self-efficacy in a new behavior can develop }\end{aligned}$

"insulin intensification is an essential element of diabetes management," 30\% of primary care physicians "never or rarely" personally intensified insulin (vs 4\% of specialists) in the multinational survey MODIFY [14, 81]. Interestingly, in a recent multinational survey, HCPs generally preferred a gradual and safe approach to titration to avoid hypoglycemia whereas patients are frustrated by time to reach goal [66]. It is therefore important to manage the patient's expectations.
The starting dose for basal insulin recommended by this panel is $10 \mathrm{U} /$ day. The dose should be incrementally increased on a regular basis using target FBG as the determinant for dose adjustments. At initiation, educating patients that many people will need at least 40-50 units of basal insulin to achieve target FBG is useful for goal setting and behavior shaping. This may help mitigate patient fear/ reluctance to up-titrate [8]. 
Table 5 Basal insulins

\begin{tabular}{|c|c|c|c|c|c|}
\hline \multicolumn{2}{|c|}{ Insulin classification } & \multirow{2}{*}{$\begin{array}{c}\begin{array}{c}\text { Duration } \\
\text { of action }\end{array} \\
\sim 18 \mathrm{~h}\end{array}$} & \multirow{2}{*}{$\begin{array}{l}\text { CV safety } \\
-\end{array}$} & \multirow{2}{*}{$\begin{array}{l}\begin{array}{l}\text { Risk of nocturnal } \\
\text { hypoglycemia }\end{array} \\
+++\end{array}$} & \multirow{2}{*}{$\begin{array}{l}\text { Considerations } \\
\text { Needs resuspension } \\
\text { Administered usually twice daily }\end{array}$} \\
\hline $\begin{array}{l}\text { Intermediate- } \\
\text { acting }\end{array}$ & $\mathrm{NPH}$ & & & & \\
\hline Long-acting & Detemir & $16-24 \mathrm{~h}$ & - & ++ & Administered once or twice daily \\
\hline & Gla-100 & $\sim 24 \mathrm{~h}$ & $\begin{array}{l}\text { Demonstrated } \\
\quad \text { (neutral) }\end{array}$ & ++ & $\begin{array}{l}\text { Administered once daily, same time } \\
\text { of day } \\
\text { Available in a fixed-ratio } \\
\text { combination with lixisenatide }\end{array}$ \\
\hline \multirow[t]{2}{*}{$\begin{array}{l}\text { Next } \\
\quad \text { generation }\end{array}$} & $\begin{array}{l}\text { Gla-300 } \\
\text { (U300) }\end{array}$ & $\sim 30 \mathrm{~h}^{\mathrm{b}}$ & $\begin{array}{l}\text { Demonstrated }^{\mathrm{a}} \\
\quad \text { (neutral) }\end{array}$ & + & $\begin{array}{l}\text { Smaller volume (U300) } \\
\text { Administered once daily } \\
\text { Flexible }+\end{array}$ \\
\hline & $\begin{array}{c}\text { Degludec } \\
\text { (U100, } \\
\text { U200) }\end{array}$ & $\sim 30 \mathrm{~h}^{\mathrm{b}}$ & $\begin{array}{l}\text { Demonstrated } \\
\quad \text { (neutral) }\end{array}$ & + & $\begin{array}{l}\text { Option smaller volume (U200) } \\
\text { Administered once daily } \\
\text { Flexible }++ \\
\text { U100 available in a fixed-ratio } \\
\text { combination with liraglutide }\end{array}$ \\
\hline
\end{tabular}

Duration of action and considerations: http://guidelines.diabetes.ca/fullguidelines/chapter12; [14, 29, 68-78]. Degludec and Gla-300 studies: [18, 20-28, 30-32, 70, 79, 80]

Gla-100 glargine $100 \mathrm{U} / \mathrm{mL}$, Gla-300 glargine $300 \mathrm{U} / \mathrm{mL}$

+ Insulins with low risk of hypoglycemia; ++ Insulins with moderate risk of hypoglycemia; +++ Insulins with higher risk of causing hypoglycemia

${ }^{a}$ Based on results from ORIGIN with Gla-100

b $\mathrm{PK} / \mathrm{PD}$ studies at $0.4 \mathrm{U} / \mathrm{kg}$

Box 1A details the recommendations by the panel for basal insulin dose and titration.
Box 1B provides a summary of key recommendations, including a starting dose and titration schedule. 


\section{Basal Insulin Dose and Titration Recommendations (2017)}

Box 1A: 2017 recommendations by the panel for basal insulin dose and titration

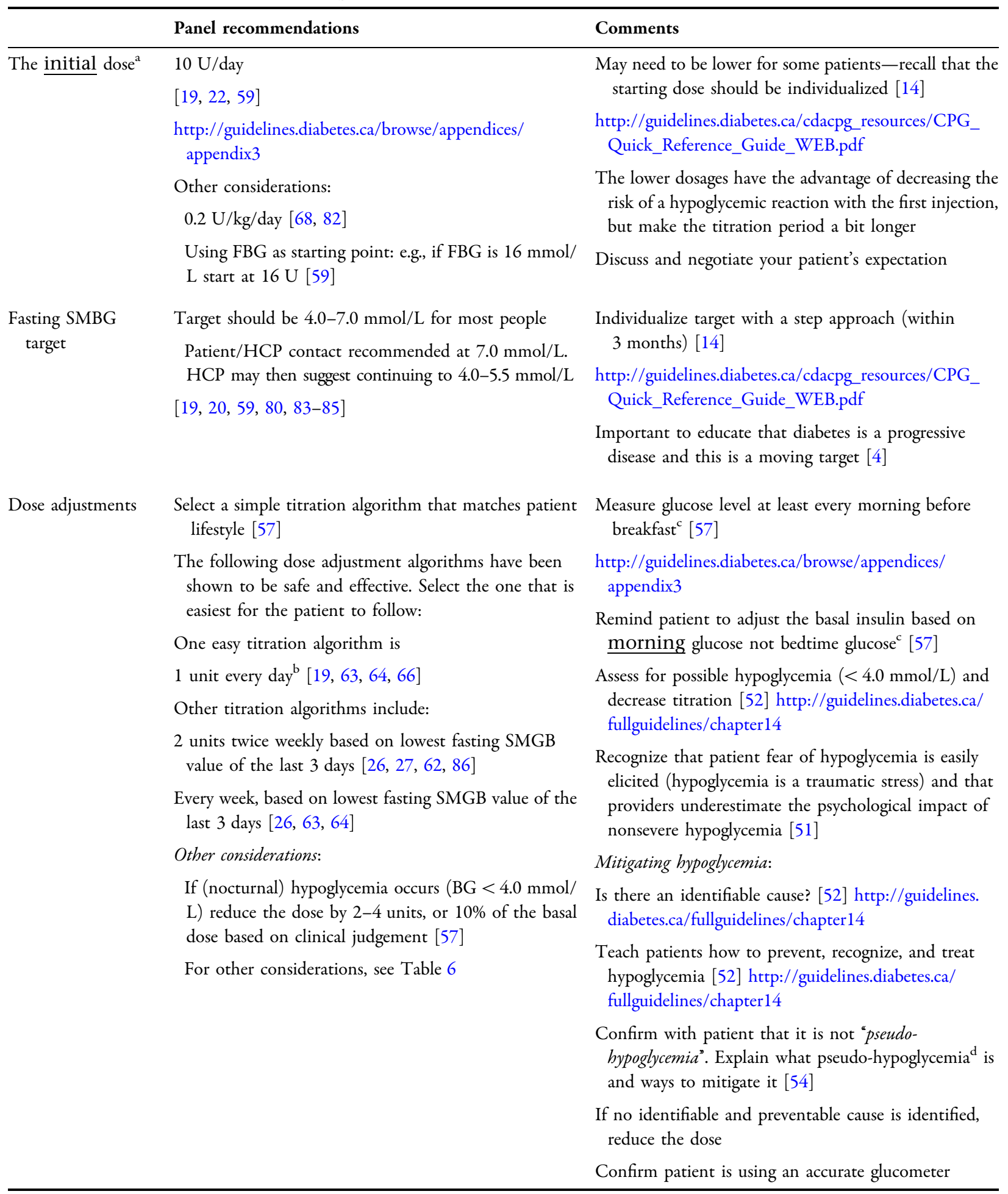


Table a continued

\begin{tabular}{|c|c|c|}
\hline & Panel recommendations & Comments \\
\hline \multirow{5}{*}{$\begin{array}{l}\text { Optimal/maximum } \\
\text { basal insulin dose }\end{array}$} & Educate the patient of their expected dose $[3,57]$ & Indication that basal insulin is not enough includes: \\
\hline & $\begin{array}{l}\text { In most studies: } 40 \text { to } 50 \text { units is needed } \\
{[8,19,26,27,66]}\end{array}$ & \multirow{2}{*}{$\begin{array}{l}\text { Up-titrations without a corresponding drop on BG } \\
\text { (verify patient adherence and check injection sites). } \\
\text { http://www.fit } 4 \text { diabetes.com/canada-english/fit- } \\
\text { recommendations/ }\end{array}$} \\
\hline & \multirow{3}{*}{$\begin{array}{l}\text { Communicate how long it will take them to reach } \\
\text { target (e.g., if the expected dose is } 60 \text { units at } 1 \mathrm{U} / \text { day } \\
\text { increase, then it will take on average } 6 \text { weeks) }\end{array}$} & \\
\hline & & $\begin{array}{l}\text { Patient has surpassed } 1 \mathrm{U} / \mathrm{kg} / \text { day of basal insulin } \\
\text { without sufficient FBG control [87] }\end{array}$ \\
\hline & & FBG in target, but A1C above target \\
\hline
\end{tabular}

$B G$ blood glucose, $F B G$ fasting blood glucose, $S M B G$ self-monitored blood glucose

${ }^{a}$ For more information on how to handle any oral agents and other FAQs, see Tables 6 and 7

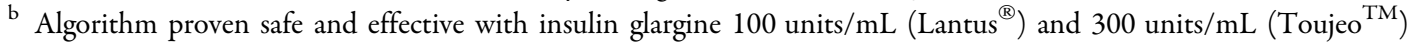

c Adjust accordingly if shift worker

d Pseudo-hypoglycemia: an event in which the patient experiences symptoms of hypoglycemia with a BG $>3.9$ mmol/L but approaching that level [54]

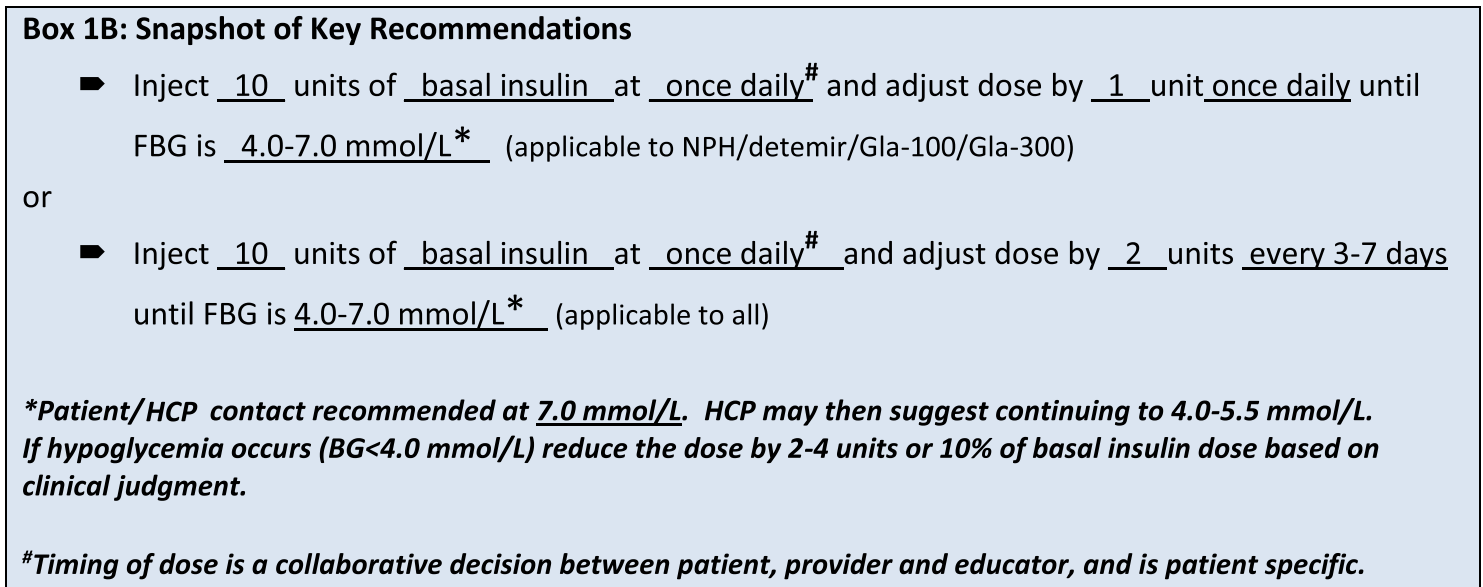


Table 6 Frequently asked questions and concerns

Question
Is 4.0 to $7.0 \mathrm{mmol} / \mathrm{L}$ too
aggressive?
Is there a ceiling to titration
process?

What to do if daytime hypoglycemia occurs while on secretagogues?

When is it appropriate to intensify treatment with another agent?

What to do if sickness occurs?

What to do if patient has recently been hospitalized for a few days?

What to do if unsure whether the dose was given?

\section{Answer}

Depends on individual target and patient characteristics (e.g., younger patient, patient with established retinopathy/nephropathy, etc.). http://guidelines.diabetes.ca/cdacpg resources/CPG_Quick_Reference_Guide_WEB.pdf

There is no such thing as a maximum dose [8]

Consider resuming titration when FBG values are above patient-agreed target for 3 consecutive days; resume 1 unit daily titration unti $\mathrm{FBG}<7.0 \mathrm{mmol} / \mathrm{L}$ is reached without hypoglycemia

Patient/HCP contact recommended at $7.0 \mathrm{mmol} / \mathrm{L}$

Dose adjustment of secretatogue and/or basal insulin recommended

If on $\mathrm{NPH}$, consider basal analogue

When A1C level remains above individual target after 3-6 months despite appropriate treatment initiation and optimization have occurred or insulin dose is $>1.0 \mathrm{U} / \mathrm{kg} /$ day. http://guidelines.diabetes.ca/cdacpg_resources/CPG_Quick_Reference_Guide_WEB. pdf

Normally continue with the usual dose of basal insulin

Test more frequently

If problems eating or hydrating: stop metformin, SGLT2 inhibitor, insulin secretagogue, ACE inhibitor, ARBs, diuretic, NSAIDs

Use SADMANS http://guidelines.diabetes.ca/browse/appendices/appendix7_2015. Complete the card (accessed by clicking on the link) and give it to your patient, including when to call and whom to reach for support [88]

Verify if the dosages were modified during the hospitalization. The dosages are often decreased as the patient eats hospital food, and must often be increased back towards the previous dosages

Do not give the dose if unsure

Test more frequently

If values rise, may consider giving half the dose [88]

\section{Additional comments:}

Suggest using supportive tools or an insulin pen that has a memory feature that will indicate if the dose was given and when 
Table 6 continued

\begin{tabular}{|c|c|}
\hline Question & Answer \\
\hline \multirow{7}{*}{$\begin{array}{l}\text { What to do if gave the dose } \\
\text { twice? }\end{array}$} & Test more frequently \\
\hline & Take extra snack at bedtime \\
\hline & Wake up every $2-3 \mathrm{~h}$ to test glucose. If $<7.0 \mathrm{mmol} / \mathrm{L}$, take an extra snack [88] \\
\hline & Additional comments: \\
\hline & Check available resources in area: \\
\hline & $\begin{array}{l}\text { For example, call a nurse for advice, diabetes educator available for support, a } 24 \mathrm{~h} \\
\text { pharmacy for a pharmacist's advice }\end{array}$ \\
\hline & Phone an "on-call" service and consider referral to ER \\
\hline \multirow[t]{5}{*}{ What to do if missed a dose? } & $\begin{array}{l}\text { If }<6 \text { h: take usual dose (be aware of potential increase in risk of hypoglycemia with next } \\
\text { injection) }\end{array}$ \\
\hline & If $6-12 \mathrm{~h}$ : take $50 \%$ of normal dose \\
\hline & $\begin{array}{l}\text { If }>12 \mathrm{~h} \text { : consider omitting dose or give } 50 \% \text { when remember and } 50 \% \text { next dose and } \\
\text { resume as per usual dosing administration schedule [89] }\end{array}$ \\
\hline & Additional comments \\
\hline & Recall that new long-acting basal insulins provide greater flexibility $[24,86]$ \\
\hline $\begin{array}{l}\text { Does insulin stacking (build-up } \\
\text { of insulin in the circulation) } \\
\text { occur with the long-acting } \\
\text { basal insulins? [90] }\end{array}$ & $\begin{array}{l}\text { No, there will be a steady state reached. The steady state will take longer to reach the } \\
\text { longer the half-life of the insulin, minimizing the fluctuations in insulin levels [90] }\end{array}$ \\
\hline \multirow{3}{*}{$\begin{array}{l}\text { When to consider seeking } \\
\text { support from other HCPs? } \\
\text { [87] }\end{array}$} & Patient has surpassed $1 \mathrm{U} / \mathrm{kg} /$ day of basal insulin without sufficient FBG control \\
\hline & Patient has recurrent episodes of hypoglycemia \\
\hline & $\begin{array}{l}\text { Patient lacks engagement in the titration process. It is important to explore reasons for } \\
\text { lack of engagement by screening for diabetes distress }\end{array}$ \\
\hline \multirow{4}{*}{$\begin{array}{l}\text { When to refer to a specialist? } \\
\text { [87] }\end{array}$} & Patient has frequent episodes of unexplained hypoglycemia \\
\hline & $\begin{array}{l}\text { Patient experiences complications (allergic reactions, lack of treatment response, edema, } \\
\text { etc.) }\end{array}$ \\
\hline & $\begin{array}{l}\text { A1C level remains above individual target after 3-6 months despite appropriate treatment } \\
\text { initiation and optimization have occurred }\end{array}$ \\
\hline & $\begin{array}{l}\text { At any point when comfort level is exceeded with available resources. It should be openly } \\
\text { acknowledged that if either the patient or provider thinks they are "in over their head," } \\
\text { accessing additional resources is appropriate }\end{array}$ \\
\hline
\end{tabular}

SGLT2 sodium-glucose co-transporter 2, ACE angiotensin-converting enzyme, $A R B$ angiotensin receptor blockers, NSAIDs non-steroidal anti-inflammatory drugs 


\section{Frequent Questions and What to Do with Previous Drugs When Initiating Basal Insulin}

Tables 6 and 7 outline some of the frequently encountered questions and concerns facing HCPs when initiating and titrating basal insulin.

\section{PATIENT SUPPORT AND MEDICAL FOLLOW-UP}

\section{How to Ensure Success of Basal Insulin Management?}

The success of basal insulin initiation and titration relies not only on identifying and addressing the patient and practitioner barriers but also on contact frequency with the patient. Post-initiation follow-up may occur by many means including via phone, text, email (depending on jurisdiction), cloud, or virtual consult. Regular contact presents an opportunity to provide or revisit diabetes education, to provide support to patients on how to effectively selfmanage their disease and to identify any causes of concern [3, 34]. Furthermore, titration should be revisited when the patient is not achieving goal, hypoglycemia occurs, or there is a change in the insulin type or brand (e.g., biosimilar) [87].

The panel provides guidelines for medical follow-up with patients in Box 2 .

Table 7 What to do with previous drugs [8, 57, 91, 92]: usually continue all current anti-hyperglycemic agents when initiating basal insulin

\begin{tabular}{|c|c|c|}
\hline Anti-hyperglycemic agent & $\begin{array}{l}\text { Anti-hyperglycemic agents } \\
\text { when initiating basal insulin }\end{array}$ & Comments \\
\hline Metformin & Continued & - \\
\hline \multirow[t]{2}{*}{$\begin{array}{l}\text { Insulin secretagogues } \\
\text { (meglitinide and sulfonylurea (SU)) }\end{array}$} & $\begin{array}{l}\text { Options to continue, reduce, } \\
\text { or stop the } \\
\text { sulfonylurea }[7,8,93]\end{array}$ & $\begin{array}{l}\text { If } S U \text { is stopped or reduced, titration of } \\
\text { insulin is even more important } \\
\text { When stopping SUs: }\end{array}$ \\
\hline & $\begin{array}{l}\text { Option to continue, reduce, } \\
\text { or stop meglitinide }[8]\end{array}$ & $\begin{array}{l}\text { Patients may need more insulin or go beyond } \\
\text { basal insulin as glucose levels may go higher } \\
\text { As a guideline, stopping SU is equivalent to } \\
\text { about } 20 \mathrm{U} \text { of insulin. Individual results } \\
\text { necessitate monitoring and titration [94] }\end{array}$ \\
\hline TZDs & Usually discontinued $^{\mathrm{a}}[95]$ & $\begin{array}{l}\text { Due to increased risk of edema and heart } \\
\text { failure with insulin }[8,96]\end{array}$ \\
\hline Incretin agents (GLP-1R agonist, DPP4i) & Continued $^{\mathrm{a}}[8,97]$ & - \\
\hline SGLT2 inhibitor & Continued & - \\
\hline
\end{tabular}

$G L P$ - $1 R$ glucagon-like peptide-1 receptor, $D P P 4 i$ protease dipeptidyl peptidase-4 inhibitor, $S G L T 2$ sodium-glucose cotransporter 2, TZD thiazolidinedione

${ }^{a}$ Recommendation to decrease TZDs is not indicated in Canada; linagliptin use with insulin is off-label (Trajenta ${ }^{\circledR}$ ) 


\section{Panel Recommendations for Medical Follow-up with Diabetes HCPs}

Box 2: panel recommendations for medical follow-up with diabetes HCPs $[87,91]$

\begin{tabular}{|c|c|}
\hline When & What and why \\
\hline $24-72 \mathrm{~h}$ & $\begin{array}{l}\text { When initiating insulin or titration } \\
\text { Support insulin initiation and } \\
\text { reinforce titration }\end{array}$ \\
\hline $1-2$ week $(s)$ & $\begin{array}{l}\text { Patients report BG readings } \\
\text { Ensure titration is occurring } \\
\text { normally }\end{array}$ \\
\hline 1 month & $\begin{array}{l}\text { Patients report BG readings } \\
\text { Ensure titration is occurring } \\
\text { normally (it is encouraged to } \\
\text { continue with biweekly contacts } \\
\text { thereafter) }\end{array}$ \\
\hline 3 months & $\begin{array}{l}\text { A1C measurement } \\
\text { If not at goal, patient may continue } \\
\text { with titration for another } 3 \text { months } \\
\text { This contact point should occur in } \\
\text { person or by virtual consult }\end{array}$ \\
\hline 6 months & $\begin{array}{l}\text { A1C measurement } \\
\text { Follow-up of titration } \\
\text { If A1C above target, review glycemic } \\
\text { profile and consider adding } \\
\text { mealtime insulin }\end{array}$ \\
\hline $\begin{array}{l}\text { Within } 24 \mathrm{~h} \text { of } \\
\text { hypoglycemia }\end{array}$ & $\begin{array}{l}\text { Educate patient on recognizing, } \\
\text { preventing, and treating } \\
\text { hypoglycemia } \\
\text { If recurrent hypoglycemia occurs, re- } \\
\text { evaluate titration schedule or } \\
\text { reduce dose (frequent, recurrent } \\
\text { hypoglycemia is typically defined as } \\
1-2 \text { lows in } 1 \text { week) }\end{array}$ \\
\hline
\end{tabular}

\section{CONCLUSION}

Several factors underlie the importance of the initiative put forth by this expert panel: there is a rising prevalence of diabetes [98]; half of the T2D population is not at target, among which $61 \%$ were receiving insulin therapy [99], suggesting delayed insulin initiation and intensification; there are multiple titration algorithms to choose from which adds to the confusion and complexity for patients and providers; and the arrival of new long-acting basal insulins and other pharmacological and technological advances that require consideration. This document was developed by a multidisciplinary panel to address frequently asked questions on insulin initiation and titration, and it establishes simple and practical guidelines for diabetes HCPs for effective initiation and titration of basal insulin, with the intent that it may translate to effective glycemic outcomes in clinical practice.

\section{Compliance with Ethical Guidelines}

This article is based on previously conducted studies and does not contain any studies with human participants or animals performed by any of the authors.

\section{ACKNOWLEDGEMENTS}

Funding. This publication was supported by Sanofi-Aventis Canada (Laval, Quebec), who funded editorial and managerial support in the preparation of this publication, provided by a third party, HIT Global Consulting Services Inc. The article processing charges were also funded by Sanofi-aventis Canada (Laval, Quebec).

Medical Writing and Editorial Assistance. The manuscript was designed, drafted, and edited by the panel with the help of medical writer, Maria Ferraiuolo of HIT Global Consulting Services Inc. The authors, individually and collectively, were responsible for content and editorial decisions.

Authorship. The manuscript was conceived by the panel of experts recognized here as the co-authors. All named authors meet the 
International Committee of Medical Journal Editors (ICMJE) criteria for authorship for this article, take responsibility for the integrity of the work as a whole, and have given their approval for this version to be published. All authors had full access to all of the data used for this article and take complete responsibility for the integrity and accuracy of the data analysis.

Disclosures. Lori Berard has received consultancy/advisory board honorarium from Sanofi, Novo Nordisk, Eli Lilly, BD, and MontMed. Noreen Antonishyn has received consultancy/advisory board honorarium from Sanofi. Kathryn Arcudi has received consultancy/advisory board honorarium from Janssen, Abbott Nutrition, Astra Zeneca, Eli Lilly, and Sanofi. Sarah Blunden has received consultancy/advisory board honorarium from Ascencia, Abbott Diabetes, Eli Lilly, Medtronic, Roche Diagnostics, and Sanofi. Alice Cheng has received consultancy/advisory board honorarium, speaker honorarium, or research support from Abbott, AstraZeneca, Boehringer Ingelheim, Eli Lilly, Janssen, Merck, Novo Nordisk, Sanofi, Servier, and Takeda. Ronald Goldenberg has received consultancy/advisory board honorarium, speaker honorarium, or research support from Eli Lilly, Novo Nordisk, and Sanofi. Stewart Harris has received consultancy/advisory board honorarium or research support from Sanofi, Novo Nordisk, AstraZeneca, Bi/ Lilly, Merck, and Janssen. Shelley Jones has received consultancy/advisory board honorarium from Abbott, AZ, Janssen, Eli Lilly, Merck, Novo Nordisk, and Sanofi. Upender Mehan has received consultancy/advisory board honorarium or unrestricted funding from Sanofi, AstraZeneca, Amgen, Janssen, Novo Nordisk, and Dairy Farmers of Canada. James Morrell has received consultancy/advisory board honorarium or research support from AstraZeneca, Novo Nordisk, Island Health, Janssen, Eli Lilly, Abbott, and MontMed. Robert Roscoe has received consultancy/advisory board honorarium or speaker honorarium/other from Novo Nordisk, Abbott Diabetes Care, Janssen, AstraZeneca, Merck Canada, Sanofi Canada, Banting \& Best Diabetes Program, New Brunswick Government, Becton-Dickinson Canada, Novo
Nordisk Canada, Bayer Healthcare, BMS AstraZeneca, Pfizer Canada, Eli Lilly Canada, Medtronic Canada, Abbott Diabetes Care, Roche Diagnostics, Canadian Pharmacists Association, Canadian Diabetes Association, and New Brunswick Pharmacists Association. Rick Siemens has received consultancy/advisory board honorarium from Sanofi, AstraZeneca, Novo Nordisk, Lilly, Janssen, and Merck. Michael Vallis has received consultancy/advisory board honorarium, speaker honorarium, or research support from Sanofi, Novo Nordisk, Abbvie, Valeant, Merck, CSL Behring, and Pfizer. JeanFrançois Yale has received consultancy/advisory board honorarium or research support from Sanofi, Novo Nordisk, Eli Lilly, and Mylan.

Compliance with Ethics Guidelines. This article is based on previously conducted studies and does not contain any studies with human participants or animals performed by any of the authors.

Open Access. This article is distributed under the terms of the Creative Commons Attribution-NonCommercial 4.0 International License (http://creativecommons.org/licenses/ by-nc/4.0/), which permits any noncommercial use, distribution, and reproduction in any medium, provided you give appropriate credit to the original author(s) and the source, provide a link to the Creative Commons license, and indicate if changes were made.

\section{REFERENCES}

1. DeFronzo RA, Eldor R, Abdul-Ghani M. Pathophysiologic approach to therapy in patients with newly diagnosed type 2 diabetes. Diabetes Care. 2013;36(Suppl 2):S127-38.

2. Pratley RE. The early treatment of type 2 diabetes. Am J Med. 2013;126(9 Suppl 1):S2-9.

3. Ross SA. Breaking down patient and physician barriers to optimize glycemic control in type 2 diabetes. Am J Med. 2013;126(9 Suppl 1):S38-48.

4. Barag SH. Insulin therapy for management of type 2 diabetes mellitus: strategies for initiation and long- 
term patient adherence. J Am Osteopath Assoc. 2011;111(7 Suppl 5):S13-9.

5. Lebovitz HE. Diabetes Review 1999;7(3):139-53.

6. Palumbo PJ. The case for insulin treatment early in type 2 diabetes. Cleve Clin J Med. 2004;71(5):385-6.

7. Holman RR, Farmer AJ, Davies MJ, et al. Three-year efficacy of complex insulin regimens in type 2 diabetes. N Engl J Med. 2009;361(18):1736-47.

8. Cheng AYY. The rules of 3s: insulin use in type 2 diabetes. Can Diabetes. 2011;24(1):3-9.

9. Lovshin JA, Zinman B. Diabetes: clinical inertia-a barrier to effective management of T2DM. Nat Rev Endocrinol. 2013;9(11):635-6. https://doi.org/10. 1038/nrendo.2013.185.

10. Phillips LS, Branch WT, Cook CB, et al. Clinical inertia. Ann Intern Med. 2001;135(9):825-34.

11. Khunti K. Clinical inertia in the management of type 2 diabetes mellitus: a focused literature review. Br J Diabetes. 2015;15(2):65-9.

12. Khunti K, Wolden ML, Thorsted BL, Andersen M, Davies MJ. Clinical inertia in people with type 2 diabetes: a retrospective cohort study of more than 80,000 people. Diabetes Care. 2013;36(11):3411-7. https://doi.org/10.2337/dc13-0331.

13. Harris SB, Kapor J, Lank CN, Willan AR, Houston T. Clinical inertia in patients with T2DM requiring insulin in family practice. Can Fam Phys. 2010;56(12):e418-24.

14. Khunti K, Millar-Jones D. Clinical inertia to insulin initiation and intensification in the UK: a focused literature review. Prim Care Diabetes. 2017;11(1):3-12.

15. Cheng AY, et al. Barriers to achieve A1C target in patients with T2D: Key learnings from a Canadian personal practice assessment. December 2015; IDF/ WDC Meeting 0738-P.

16. Ng CJ, Lai PS, Lee YK, Azmi SA, Teo CH. Barriers and facilitators to starting insulin in patients with type 2 diabetes: a systematic review. Int J Clin Pract. 2015;69(10):1050-70.

17. Kunt T, Snoek FJ. Barriers to insulin initiation and intensification and how to overcome them. Int $\mathrm{J}$ Clin Pract Suppl. 2009;164:6-10.

18. Gerstein HC, Bosch J, Dagenais GR, et al. Basal insulin and cardiovascular and other outcomes in dysglycemia. N Engl J Med. 2012;367(4):319-28.
19. Gerstein HC, Yale JF, Harris SB, Issa M, Stewart JA, Dempsey E. A randomized trial of adding insulin glargine vs. avoidance of insulin in people with type 2 diabetes on either no oral glucose-lowering agents or submaximal doses of metformin and/or sulphonylureas. The Canadian INSIGHT (Implementing New Strategies with Insulin Glargine for Hyperglycaemia Treatment) Study. Diabet Med. 2006;23(7):736-42.

20. Ritzel R, Roussel R, Bolli GB, et al. Patient-level meta-analysis of the EDITION 1, 2 and 3 studies: glycaemic control and hypoglycaemia with new insulin glargine $300 \mathrm{U} / \mathrm{ml}$ versus glargine $100 \mathrm{U} / \mathrm{ml}$ in people with type 2 diabetes. Diabetes Obes Metab. 2015;17(9):859-67.

21. Riddle MC, Bolli GB, Ziemen M, Muehlen-Bartmer I, Bizet F, Home PD. New insulin glargine 300 units/ $\mathrm{mL}$ versus glargine 100 units/mL in people with type 2 diabetes using basal and mealtime insulin: glucose control and hypoglycemia in a 6-month randomized controlled trial (EDITION 1). Diabetes Care. 2014;37(10):2755-62.

22. Yki-Jarvinen H, Bergenstal R, Ziemen M, Wardecki M, Muehlen-Bartmer I, Boelle E, et al. New insulin glargine 300 units $/ \mathrm{mL}$ versus glargine 100 units $/ \mathrm{mL}$ in people with type 2 diabetes using oral agents and basal insulin: glucose control and hypoglycemia in a 6-month randomized controlled trial (EDITION 2). Diabetes Care. 2014;37(12):3235-43.

23. Bolli GB, Riddle MC, Bergenstal RM, et al. New insulin glargine $300 \mathrm{U} / \mathrm{ml}$ compared with glargine $100 \mathrm{U} / \mathrm{ml}$ in insulin-naive people with type 2 diabetes on oral glucose-lowering drugs: a randomized controlled trial (EDITION 3). Diabetes Obes Metab. 2015;17(4):386-94.

24. Riddle MC, Bolli GB, Home PD, et al. Efficacy and safety of flexible versus fixed dosing intervals of insulin glargine $300 \mathrm{U} / \mathrm{mL}$ in people with type 2 diabetes. Diabetes Technol Ther. 2016;18(4):252-7.

25. Matsuhisa $M$, Koyama $M$, Cheng $X$, et al. New insulin glargine $300 \mathrm{U} / \mathrm{ml}$ versus glargine $100 \mathrm{U} / \mathrm{ml}$ in Japanese adults with type 1 diabetes using basal and mealtime insulin: glucose control and hypoglycaemia in a randomized controlled trial (EDITION JP 1). Diabetes Obes Metab. 2016;18(4):375-83.

26. Zinman B, Philis-Tsimikas A, Cariou B, et al. Insulin degludec versus insulin glargine in insulin-naive patients with type 2 diabetes: a 1-year, randomized, treat-to-target trial (BEGIN Once Long). Diabetes Care. 2012;35(12):2464-71.

27. Gough SC, Bhargava A, Jain R, Mersebach H, Rasmussen S, Bergenstal RM. Low-volume insulin degludec 200 units $/ \mathrm{ml}$ once daily improves 
glycemic control similarly to insulin glargine with a low risk of hypoglycemia in insulin-naive patients with type 2 diabetes: a 26-week, randomized, controlled, multinational, treat-to-target trial: the BEGIN LOW VOLUME trial. Diabetes Care. 2013;36(9):2536-42.

28. Onishi Y, Iwamoto Y, Yoo SJ, Clauson P, Tamer SC, Park S. Insulin degludec compared with insulin glargine in insulin-naive patients with type 2 diabetes: a 26-week, randomized, controlled, PanAsian, treat-to-target trial. J Diabetes Investig. 2013;4(6):605-12.

29. Standl E, Owen DR. New long-acting basal insulins: does benefit outweigh cost? Diabetes Care. 2016;39(Supplement 2):S172-9.

30. Terauchi Y, Koyama M, Cheng X, et al. New insulin glargine $300 \mathrm{U} / \mathrm{ml}$ versus glargine $100 \mathrm{U} / \mathrm{ml}$ in Japanese people with type 2 diabetes using basal insulin and oral antihyperglycaemic drugs: glucose control and hypoglycaemia in a randomized controlled trial (EDITION JP 2). Diabetes Obes Metab. 2016;18(4):366-74.

31. Home PD, Bergenstal RM, Bolli GB, et al. New insulin glargine 300 units/mL versus glargine 100 Units/mL in people with type 1 diabetes: a randomized, phase 3a, open-label clinical trial (EDITION 4). Diabetes Care. 2015;38(12):2217-25.

32. Garber AJ, King AB, Del Prato $\mathrm{S}$, et al. Insulin degludec, an ultra-longacting basal insulin, versus insulin glargine in basal-bolus treatment with mealtime insulin aspart in type 2 diabetes (BEGIN Basal-Bolus Type 2): a phase 3, randomised, openlabel, treat-to-target non-inferiority trial. Lancet. 2012;379(9825):1498-507.

33. Polinski JM, Smith BF, Curtis BH, et al. Barriers to insulin progression among patients with type 2 diabetes: a systematic review. Diabetes Educ. 2013;39(1):53-65.

34. Powers MA, Bardsley J, Cypress M, et al. Diabetes self-management education and support in type 2 diabetes. Diabetes Educ. 2017;43(1):40-53. https:// doi.org/10.1177/0145721716689694.

35. Al Hamarneh YN, Charrois T, Lewanczuk R, Tsuyuki RT. Pharmacist intervention for glycaemic control in the community (the RxING study). BMJ Open. 2013;3(9):e003154.

36. Furler J, O'Neal D, Speight J, et al. Supporting insulin initiation in type 2 diabetes in primary care: results of the Stepping Up pragmatic cluster randomised controlled clinical trial. BMJ. 2017;356:j783.
37. Kovacs Burns K, Nicolucci A, Holt RI, et al. Diabetes attitudes, wishes and needs second study (DAWN2): cross-national benchmarking indicators for family members living with people with diabetes. Diabet Med. 2013;30(7):778-88.

38. Peyrot M, Burns KK, Davies M, et al. Diabetes attitudes wishes and needs 2 (DAWN2): a multinational, multi-stakeholder study of psychosocial issues in diabetes and person-centred diabetes care. Diabetes Res Clin Pract. 2013;99(2):174-84.

39. Funnell MM. Overcoming barriers to the initiation of insulin therapy. Clin Diabetes. 2007;25(1):36-8.

40. Meece J. Dispelling myths and removing barriers about insulin in type 2 diabetes. Diabetes Educ. 2006;32(1 Suppl):9S-18S.

41. Skovlund SE, Peyrot M. The diabetes attitudes, wishes, and needs (DAWN) program: a new approach to improving outcomes of diabetes care. Diabetes Spect. 2005;18(3):136-42.

42. Polonsky WH, Jackson RA. What's so tough about taking insulin? Addressing the problem of psychological insulin resistance in type 2 diabetes. Clin Diabetes. 2004;22(3):147-50.

43. Polonsky WH, Fisher L, Guzman S, Villa-Caballero L, Edelman SV. Psychological insulin resistance in patients with type 2 diabetes: the scope of the problem. Diabetes Care. 2005;28(10):2543-5.

44. Davies MJ, Gagliardino JJ, Gray LJ, Khunti K, Mohan V, Hughes R. Real-world factors affecting adherence to insulin therapy in patients with type 1 or type 2 diabetes mellitus: a systematic review. Diabet Med. 2013;30(5):512-24.

45. Karter AJ, Subramanian U, Saha C, et al. Barriers to insulin initiation: the translating research into action for diabetes insulin starts project. Diabetes Care. 2010;33(4):733-5.

46. Lebovitz HE. Type 2 diabetes: an overview. Clin Chem. 1999;45(8 Pt 2):1339-45.

47. UK Prospective Diabetes Study (UKPDS) Group. Intensive blood-glucose control with sulphonylureas or insulin compared with conventional treatment and risk of complications in patients with type 2 diabetes (UKPDS 33). Lancet. 1998;352(9131):837-53.

48. Holman RR, Paul SK, Bethel MA, Matthews DR, Neil HAW. 10-year follow-up of intensive glucose control in type 2 diabetes. $\mathrm{N}$ Engl $\mathrm{J}$ Med. 2008;359(15):1577-89.

49. Kostev K, Dippel FW, Rathmann W. Risk of hypoglycaemia in type 2 diabetes patients under 
different insulin regimens: a primary care database analysis. Ger Med Sci. 2015;12(13):Doc01.

50. Polonsky WH, Fisher L, Hessler D, Edelman SV. Identifying the worries and concerns about hypoglycemia in adults with type 2 diabetes. J Diabetes Complic. 2015;29(8):1171-6.

51. Vallis M, Jones A, Pouwer F. Managing hypoglycemia in diabetes may be more fear management than glucose management: a practical guide for diabetes care providers. Curr Diabetes Rev. 2014;10(6):364-70.

52. Clayton D, Woo V, Yale J-F. Canadian Diabetes Association 2013 Clinical Practice Guidelines for the Prevention and Management of Diabetes in Canada: hypoglycemia. Can J Diabetes 2013;37(suppl 1):S69-71.

53. Harper W, Clement M, Goldenberg R, et al. Canadian Diabetes Association 2013 Clinical Practice Guidelines for the Prevention and Management of Diabetes in Canada: pharmacologic management of type 2 diabetes. Can J Diabetes 2013;37(suppl 1):S61-68.

54. Seaquist ER, Anderson J, Childs B, et al. Hypoglycemia and diabetes: a report of a workgroup of the American Diabetes Association and the Endocrine Society. Diabetes Care. 2013;36(5):1384-95.

55. Sorli C, Heile MK. Identifying and meeting the challenges of insulin therapy in type 2 diabetes. J Multidiscip Healthc. 2014;7:267-82.

56. Polonsky WH, Arsenault J, Fisher L, et al. Initiating insulin: how to help people with type 2 diabetes start and continue insulin successfully. Int J Clin Pract. 2017. https://doi.org/10.1111/ijcp.12973.

57. Arnolds S, Heise T, Flacke F, Sieber J. Common standards of basal insulin titration in type 2 diabetes. J Diabetes Sci Technol. 2013;7(3):771-88.

58. Sabourin BC, Pursley S. Psychosocial issues in diabetes self-management: strategies for healthcare providers. Can J Diabetes. 2013;37(1):36-40.

59. Davies M, Storms F, Shutler S, Bianchi-Biscay M, Gomis R. Improvement of glycemic control in subjects with poorly controlled type 2 diabetes: comparison of two treatment algorithms using insulin glargine. Diabetes Care. 2005;28(6):1282-8.

60. Blonde L, Merilainen M, Karwe V, Raskin P. Patientdirected titration for achieving glycaemic goals using a once-daily basal insulin analogue: an assessment of two different fasting plasma glucose targets-the TITRATE study. Diabetes Obes Metab. 2009;11(6):623-31.
61. Meneghini L, Koenen C, Weng W, Selam JL. The usage of a simplified self-titration dosing guideline (303 Algorithm) for insulin detemir in patients with type 2 diabetes-results of the randomized, controlled PREDICTIVE 303 study. Diabetes Obes Metab. 2007;9(6):902-13.

62. Philis-Tsimikas A, Brod M, Niemeyer M, Ocampo Francisco AM, Rothman J. Insulin degludec oncedaily in type 2 diabetes: simple or step-wise titration (BEGIN: once simple use). Adv Ther. 2013;30(6):607-22.

63. Berard L, Harris SB, Yale J-F, Groleau M, Javadi P, Stewart J. Safety and efficacy of a pragmatic selftitration 1 unit/day (INSIGHT) algorithm for insulin glargine $300 \mathrm{U} / \mathrm{mL}$ (Gla-300). Can J Diabetes. 2016;40(5):S47.

64. Yale JF, Berard L, Groleau M, Javadi P, Stewart J, Harris SB. TITRATION: a randomized study to assess 2 treatment algorithms with new insulin glargine 300 units/ml. Can J Diabetes. 2017;41(5):478-84. https://doi.org/10.1016/j.jcjd.2017.06.007.

65. Peyrot M, Barnett AH, Meneghini LF, SchummDraeger PM. Insulin adherence behaviours and barriers in the multinational global attitudes of patients and physicians in insulin therapy study. Diabet Med. 2012;29(5):682-9.

66. Berard L, Bonnemaire M, Mical M, Edelman S. Insights into optimal basal insulin titration in type 2 diabetes: results of a quantitative survey. Diabetes Obes Metab. 2018;20(2):301-8.

67. Owens DR, Matfin G, Monnier L. Basal insulin analogues in the management of diabetes mellitus: what progress have we made? Diabetes Metab Res Rev. 2014;30(2):104-19.

68. TOUJEO $^{\mathrm{TM}}$ SoloSTAR ${ }^{\circledR}$ Product Monograph May 28, 2015.

69. FPD. Clinical pharmacology and biopharmaceutics review(s). 2015. https://www.accessdata.fda.gov/ drugsatfda_docs/nda/2015/203313Orig1s000_2033 14Orig1s000ClinPharmR.pdf.

70. Marso SP, McGuire DK, Zinman B, et al. Efficacy and safety of degludec versus glargine in type 2 diabetes. N Engl J Med. 2017;377:723-32.

71. Heise T, Nosek L, Bottcher SG, Hastrup H, Haahr H. Ultra-long-acting insulin degludec has a flat and stable glucose-lowering effect in type 2 diabetes. Diabetes Obes Metab. 2012;14(10):944-50.

72. Lajara R, Cengiz E, Tanenberg RJ. The role of the new basal insulin analogs in addressing unmet clinical needs in people with type 1 and type 2 diabetes. Curr Med Res Opin. 2017;33(6):1045-55. 
73. Bramlage $\mathrm{P}$, Bluhmki $\mathrm{T}$, Fleischmann $\mathrm{H}$, et al. Determinants of weight change in patients on basal insulin treatment: an analysis of the DIVE registry. BMJ. 2017;5(1):e000301.

74. Garber AJ. Will the next generation of basal insulins offer clinical advantages? Diabetes Obes Metab. 2014;16(6):483-91.

75. Owens DR. Clinical evidence for the earlier initiation of insulin therapy in type 2 diabetes. Diabetes Technol Ther. 2013;15:776-85.

76. Steinstraesser A, Schmidt R, Bergmann K, Dahmen $\mathrm{R}$, Becker $\mathrm{RH}$. Investigational new insulin glargine $300 \mathrm{U} / \mathrm{ml}$ has the same metabolism as insulin glargine $100 \mathrm{U} / \mathrm{ml}$. Diabetes Obes Metab. 2014;16(9):873-6.

77. Goldman J, Kapitza C, Pettus J, Heise T. Understanding how pharmacokinetic and pharmacodynamic differences of basal analog insulins influence clinical practice. Curr Med Res Opin. 2017;33(10):1821-31.

78. de Galan BE. Insulin glargine $300 \mathrm{U} / \mathrm{mL}$ in the management of diabetes: clinical utility and patient perspectives. Patient Prefer Adher. 2016;10:2097-106.

79. Becker RH, Dahmen R, Bergmann K, Lehmann A, Jax T, Heise T. New insulin glargine 300 units. mL-1 provides a more even activity profile and prolonged glycemic control at steady state compared with insulin glargine 100 units. mL-1. Diabetes Care. 2015;38(4):637-43. https://doi.org/10.2337/dc140006 .

80. Marso SP, McGuire DK, Zinman B, et al. Design of DEVOTE (trial comparing cardiovascular safety of insulin degludec vs insulin glargine in patients with type 2 diabetes at high risk of cardiovascular events) - DEVOTE 1. Am Heart J. 2016;179:175-83. https:// doi.org/10.1016/j.ahj.2016.06.004.

81. Shah BR, Hux JE, Laupacis A, Zinman B, van Walraven $C$. Clinical inertia in response to inadequate glycemic control: do specialists differ from primary care physicians? Diabetes Care. 2005;28(3):600-6.

82. Blonde L, Merilainen M, Karwe V, Raskin P, Group TS. Patient-directed titration for achieving glycaemic goals using a once-daily basal insulin analogue: an assessment of two different fasting plasma glucose targets-the TITRATE ${ }^{\mathrm{TM}}$ study. Diabetes Obes Metab. 2009;11(6):623-31.

83. Riddle MC, Rosenstock J, Gerich J. The treat-totarget trial. Randomized addition of glargine or human NPH insulin to oral therapy of type 2 diabetic patients. Diabetes Care. 2003;26(11):3080-6.
84. Yki-Jarvinen $\mathrm{H}$, Kauppinen-Makelin $\mathrm{R}$, Tiikkainen $\mathrm{M}$, et al. Insulin glargine or NPH combined with metformin in type 2 diabetes: the LANMET study. Diabetologia. 2006;49(3):442-51.

85. Harris S, Yale JF, Dempsey E, Gerstein H. Can family physicians help patients initiate basal insulin therapy successfully? Randomized trial of patient-titrated insulin glargine compared with standard oral therapy: lessons for family practice from the Canadian INSIGHT trial. Can Fam Physician. 2008;54(4):550-8.

86. Meneghini L, Atkin SL, Gough SC, et al. The efficacy and safety of insulin degludec given in variable once-daily dosing intervals compared with insulin glargine and insulin degludec dosed at the same time daily: a 26-week, randomized, open-label, parallel-group, treat-to-target trial in individuals with type 2 diabetes. Diabetes Care. 2013;36(4):858-64.

87. Partners HealthCare. Partners guidelines for the treatment of type 2 diabetes in the non-pregnant adult. Partners Healthcare; 2012. http://vdc. partners.org/guidelines/Guidelines_7-10-12.pdf.

88. Staples H, Yale JF. Starting Insulin. Booklet based on INSIGHT Study conducted 2002-2004. Aventis Pharma.

89. Glasgow Diabetes Managed Clinical Network. Guidelines for insulin initiation and adjustment in primary care in patients with type 2 diabetes: for the guidance of diabetes specialist nurses. Greater Glasgow and Clyde: NHS; 2010.

90. Heise T, Meneghini LF. Insulin stacking versus therapeutic accumulation: understanding the differences. Endocr Pract. 2014;20(1):75-83.

91. Canadian Diabetes Association Clinical Practice Guidelines Expert Committee. Canadian Diabetes Association 2013 clinical practice guidelines for the prevention and management of diabetes in Canada. Can J Diabetes. 2013;37:S1-212.

92. Canadian Diabetes Association Clinical Practice Guidelines Expert Committee. Appendix 3: Examples of insulin initiation and titration regimens in people with type 2 diabetes. Can J Diabetes 2013;37:S200-S1.

93. Bergenstal RM, Johnson M, Powers MA, et al. Adjust to target in type 2 diabetes: comparison of a simple algorithm with carbohydrate counting for adjustment of mealtime insulin glulisine. Diabetes Care. 2008;31(7):1305-10.

94. Buse JB, Wolffenbuttel BH, Herman WH, et al. The DURAbility of basal versus lispro mix 75/25 insulin Efficacy (DURABLE) trial: comparing the durability 
of lispro mix 75/25 and glargine. Diabetes Care. 2011;34(2):249-55.

95. Kennedy L, Herman WH, Strange P, Harris A. Impact of active versus usual algorithmic titration of basal insulin and point-of-care versus laboratory measurement of HbA1c on glycemic control in patients with type 2 diabetes: the Glycemic Optimization with algorithms and labs at Point of Care (GOAL A1C) trial. Diabetes Care. 2006;29(1):1-8.

96. Charbonnel B, DeFronzo R, Davidson J, et al. Pioglitazone use in combination with insulin in the prospective pioglitazone clinical trial in macrovascular events study (PROactive19). J Clin Endocrinol Metab. 2010;95(5):2163-71.
97. Arnolds S, Dellweg S, Clair J, et al. Further improvement in postprandial glucose control with addition of exenatide or sitagliptin to combination therapy with insulin glargine and metformin: a proof-of-concept study. Diabetes Care. 2010;33(7):1509-15.

98. Canadian Diabetes Association. Diabetes charter for Canada 2016. http://www.diabetes.ca/getmedia/ 513a0f6c-b1c9-4e56-a77c-6a492bf7350f/diabetescharter-backgrounder-national-english.pdf.aspx.

99. Leiter LA, Berard L, Bowering CK, et al. Type 2 diabetes mellitus management in Canada: is it improving? Can J Diabetes. 2013;37(2):82-9. 